\title{
Dose-response study of sodium cromoglycate in exercise-induced asthma
}

\author{
KR PATEL, KE BERKIN, JW KERR \\ From the Department of Respiratory Medicine, Western Infirmary, Glasgow
}

ABSTRACT Ten patients with exercise-induced asthma participated in a single-blind doseresponse study comparing the protective effect of inhaled sodium cromoglycate in increasing concentrations from 2 to $40 \mathrm{mg} / \mathrm{ml}$. Saline was used as a control. Effects were assessed from the mean maximal percentage fall in forced expiratory volume in one second $\left(F E V_{1}\right)$ after the patients had run on a treadmill for eight minutes. There was slight bronchodilation evident from the increase in baseline $\mathrm{FEV}_{1}$ after inhalation of sodium cromoglycate, the difference reaching statistical significance with the highest concentration $(5.7 \%, \mathrm{p}<0.05)$. After exercise

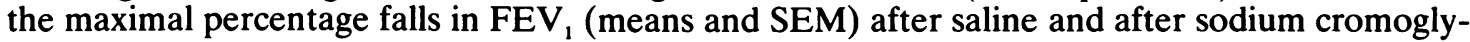
cate at $2,10,20$, and $40 \mathrm{mg} / \mathrm{ml}$ were $37 \cdot 3 \pm 4 \cdot 7,17 \cdot 3 \pm 4 \cdot 1,10 \pm 3 \cdot 3,7 \cdot 6 \pm 2 \cdot 4$, and $12 \pm 2 \cdot 9$. Sodium cromoglycate inhibited the exercise-induced fall in $\mathrm{FEV}_{1}$ at all the concentrations used in the study ( $p<0.001)$ and its inhibitory effect increased from 2 to $20 \mathrm{mg} / \mathrm{ml}$. The mean FEV returned to baseline values within 15 minutes at higher concentrations of sodium cromoglycate (20 and $40 \mathrm{mg} / \mathrm{ml}$ ) and a small bronchodilator effect was noted at 30 minutes. The findings suggest that the protective effect of sodium cromoglycate in exercise asthma is dose related. At higher concentration the drug suppresses chemical mediator release from the lung mast cells and may also modify the bronchial reactivity to release mediators.

Sodium cromoglycate suppresses the release of chemical mediators of the type I allergic reaction. ${ }^{1}$ Its inhibitory action in exercise asthma is now well documented ${ }^{2-4}$ and this effect may also be mediated through its mast-cell-stabilising property.5 A lowdose pressurised aerosol has recently been marketed. This delivers $1 \mathrm{mg}$ sodium cromoglycate per inhalation, a considerably smaller dose than the 20 $\mathrm{mg}$ in a spincapsule; but no properly conducted dose-response study of sodium cromoglycate in exercise-induced or allergen-induced asthma has been carried out. Studies have been conducted comparing sodium cromoglycate aerosol with the dry powder inhaled through a spinhaler or cromoglycate powder with cromoglycate nebuliser solution ${ }^{6}$ (see also papers by B Blohm et al and $\mathrm{N}$ Knudsen to Fourth Charles Blackley Symposium, Nottingham, 1981), there being a considerable variability in the dose and the site of drug deposited in the airways with different methods of administration. In addition, sodium cromoglycate in the dry powder form

Address for reprint requests: Dr KR Patel, Department of Respiratory Medicine, Western Infirmary, Glasgow G11 6NT. has a strong affinity for water, ${ }^{7}$ and this may lead to differences when aerosol or powder cromoglycate are compared with the nebuliser solution if respiratory heat loss and airway cooling and humidity are considered to be the important factors in bronchoconstriction after exercise. ${ }^{8}$

We have compared the effect of saline and of sodium cromoglycate nebuliser solution inhaled from a Wright's nebuliser in increasing concentrations from $2 \mathrm{mg}$ to $40 \mathrm{mg} / \mathrm{ml}$ in 10 patients with exercise-induced asthma.

\section{Methods}

We studied 10 patients, aged 17-54 years (mean 29, SEM 3.2), with bronchial asthma and airflow obstruction. All patients had positive responses to prick tests with inhalant allergens and exerciseinduced bronchoconstriction with a fall in $\mathrm{FEV}_{1}$ of $20 \%$ confirmed by previous exercise testing. Sodium cromoglycate and bronchodilator drugs were discontinued for 24 hours before each test was carried out. Patients taking oral or aerosol corticosteroids, antihistamines, and anticholinergic drugs were excluded 
Table 1 Effect of saline and sodium cromoglycate on the maximal fall from post-inhalation FEV, after exercise in 10 patients

\begin{tabular}{|c|c|c|c|c|c|c|c|}
\hline \multirow[t]{2}{*}{ No } & \multirow[t]{2}{*}{ Sex } & \multirow[t]{2}{*}{ Age } & \multirow{2}{*}{$\begin{array}{l}\text { Change in } F E V_{1}(l) \\
\text { after saline }\end{array}$} & \multicolumn{4}{|c|}{ Change in $F E V_{1}(l)$ afier sodium cromoglycate } \\
\hline & & & & $2 \mathrm{mg} / \mathrm{ml}$ & $10 \mathrm{mg} / \mathrm{ml}$ & $20 \mathrm{mg} / \mathrm{ml}$ & $40 \mathrm{mg} / \mathrm{ml}$ \\
\hline $\begin{array}{c}1 \\
2 \\
3 \\
4 \\
5 \\
6 \\
7 \\
8 \\
9 \\
10 \\
\text { Mean } \\
\text { SEM }\end{array}$ & $\begin{array}{l}\mathbf{F} \\
\mathbf{M} \\
\mathbf{M} \\
\mathbf{M} \\
\mathbf{M} \\
\mathbf{M} \\
\mathbf{M} \\
\mathbf{M} \\
\mathbf{M} \\
\mathbf{F}\end{array}$ & $\begin{array}{l}32 \\
28 \\
32 \\
17 \\
54 \\
24 \\
32 \\
22 \\
27 \\
22 \\
29 \\
3 \cdot 2\end{array}$ & $\begin{array}{r}-0.75 \\
-1.15 \\
-0.67 \\
-2.11 \\
-0.47 \\
-1.54 \\
-0.77 \\
-3.11 \\
-1.14 \\
-1.40 \\
-1.31 \\
0.25\end{array}$ & $\begin{array}{r}-0.55 \\
-0.87 \\
-0.31 \\
-0.34 \\
-0.24 \\
-0.55 \\
-0.23 \\
-1.98 \\
-0.30 \\
-0.27 \\
-0.56 \\
0.17\end{array}$ & $\begin{array}{r}-0.23 \\
-0.86 \\
-0.13 \\
-0.27 \\
-0.16 \\
-0.30 \\
-0.38 \\
-1.21 \\
-0.17 \\
-0.10 \\
-0.38 \\
0.11\end{array}$ & $\begin{array}{r}-0.40 \\
-0.53 \\
-0.20 \\
+0.10 \\
-0.03 \\
-0.20 \\
-0.10 \\
-0.54 \\
+0.06 \\
-0.07 \\
-0.19 \\
0.07\end{array}$ & $\begin{array}{r}-0.07 \\
-0.83 \\
-0.31 \\
-0.40 \\
-0.17 \\
-0.15 \\
-0.50 \\
-0.74 \\
+0.08 \\
-0.82 \\
-0.39 \\
0.10\end{array}$ \\
\hline
\end{tabular}

Table 2 Mean percentage change in $F E V$, in 10 patients after inhalation of saline and sodium cromoglycate (SCG) and at $2,5,10,15$, and 30 minutes after exercise

\begin{tabular}{|c|c|c|c|c|c|c|c|c|}
\hline & \multirow{2}{*}{$\begin{array}{l}\text { \% change in baseline } \\
F E V \text {, }\end{array}$} & \multicolumn{5}{|c|}{ \% change in FEV, at intervals (min) afier exercise } & \multicolumn{2}{|l|}{$p$} \\
\hline & & 2 & 5 & 10 & 15 & 30 & $\begin{array}{l}\text { Saline v } \\
\text { SCG }\end{array}$ & $\begin{array}{l}S C G(2 m g) \\
v S C G\end{array}$ \\
\hline $\begin{array}{l}\text { Saline } \\
\text { Sodium cromoglycate }\end{array}$ & $-1 \cdot 7$ & -21 & -36 & -35 & -31 & -24 & & \\
\hline $\begin{array}{l}2 \mathrm{mg} / \mathrm{ml} \\
10 \mathrm{mg} / \mathrm{ml} \\
20 \mathrm{mg} / \mathrm{ml} \\
40 \mathrm{mg} / \mathrm{ml}\end{array}$ & $\begin{array}{l}+3 \cdot 6 \\
+2 \cdot 2 \\
+2 \cdot 1 \\
+5 \cdot 7\end{array}$ & $\begin{array}{l}+2 \cdot 5 \\
+1 \cdot 2 \\
+6.5 \\
+1 \cdot 5\end{array}$ & $\begin{array}{l}-11.3 \\
-8.2 \\
-3.6 \\
-5.9\end{array}$ & $\begin{array}{l}-11 \cdot 0 \\
-8 \cdot 5 \\
-1 \cdot 0 \\
-4 \cdot 0\end{array}$ & $\begin{array}{l}-6.2 \\
-6.9 \\
+2.2 \\
+0.3\end{array}$ & $\begin{array}{l}-3 \cdot 0 \\
-4 \cdot 2 \\
+6.5 \\
+3 \cdot 3\end{array}$ & $\begin{array}{l}<0.001 \\
<0.001 \\
<0.001 \\
<0.001\end{array}$ & $\begin{array}{l}<0.05 \\
<0.01 \\
<0.05\end{array}$ \\
\hline
\end{tabular}

from the study. All patients were non-smokers and gave informed consent to being studied. FEV, was measured on a water-sealed spirometer (Godart Pulmotest). The best of three attempts was used for analysis and the volumes were corrected to BTPS. Predicted values were taken from Cotes. ${ }^{9}$

Exercise testing consisted of steady-state running on an inclined treadmill $\left(10^{\circ}\right)$ for up to eight minutes. The speed was so adjusted that the patient's pulse rate at the end of the exercise was 160 beats per minute. A series of five tests in each patient was completed within 10 days. The temperature on the study days varied from $20^{\circ}$ to $22^{\circ} \mathrm{C}$ and the relative humidity from $30 \%$ to $50 \%$. The study was carried out in a random single-blind fashion with physiological saline or sodium cromoglycate solution in varying concentrations $(2,10,20$, and 40 $\mathrm{mg} / \mathrm{ml}$ ). The drugs were delivered through a Wright's nebuliser driven by compressed air at a flow rate of $9 \mathrm{l} / \mathrm{min}\left(124 \mathrm{kPa}, 18 \mathrm{lb} / \mathrm{in}^{2}\right)$. All inhalations were carried out at tidal breathing for five minutes. The estimated doses of sodium cromoglycate nebulised were $2 \cdot 4,12,24$, and $48 \mathrm{mg}$ respectively. The FEV, was recorded at 30 minutes after inhalation and at two, five, 10, 15, and 30 minutes after exercise. The results of exercise tests were expressed as the maximum fall in FEV, from the post-drug baseline. The treatments were compared with an analysis of variance for overall effect, followed by Duncan's multiple-range test and Student's paired $t$ test for the dose-response effect.

\section{Results}

Tables 1 and 2 give the results. There was no significant difference between the mean baseline values of $\mathrm{FEV}_{1}$ before inhalation of saline and sodium cromoglycate on the five days of exercise testing. Saline and sodium cromoglycate at 2,10 , and $20 \mathrm{mg} / \mathrm{ml}$ did not have a significant effect on the mean FEV, 30 minutes after inhalation and before exercise. Sodium cromoglycate at these concentrations did, however, have a slight bronchodilator $\widetilde{N}$ effect (fig 1). In contrast, sodium cromoglycate at 40 $\mathrm{mg} / \mathrm{ml}$ raised the mean baseline $\mathrm{FEV}$, by 0.211 $(5.7 \%)$ and this bronchodilator effect was statistically significant ( $\mathrm{p}<0.05$, Student's paired $t$ test) (fig 1, table 2).

After exercise the mean maximum percentage falls in FEV (means and SEM) after saline and after sodium cromoglycate at $2,10,20$, and $40 \mathrm{mg} / \mathrm{ml}$ were $37 \cdot 3 \pm 4 \cdot 7,17 \cdot 3 \pm 4 \cdot 1,10 \pm 3 \cdot 3 \cdot 7 \cdot 6 \pm 2 \cdot 4$, and $12 \pm 2 \cdot 9$. Sodium cromoglycate inhibited the exercise-induced fall in $\mathrm{FEV}_{1}$ at all the concentra- 


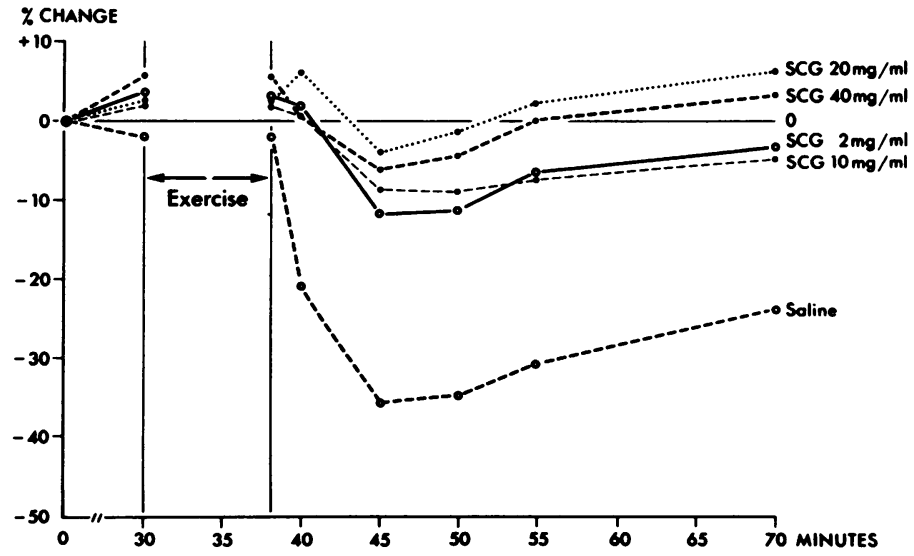

Fig 1 Mean percentage change in $F E V_{1}$ (from baseline before administration of drug) before and after exercise with saline and sodium cromoglycate.

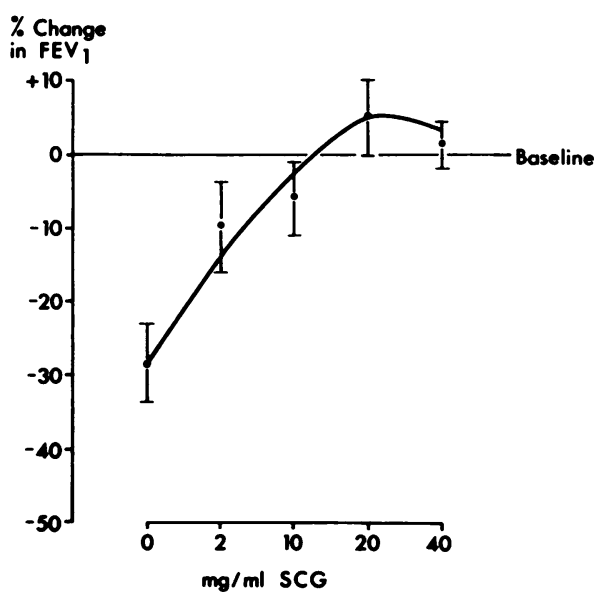

Fig 2 Mean percentage ( $\pm S E M$ ) change in $F E V_{1}$ (from baseline before administration of drug) at 15 minutes after saline and increasing concentrations of sodium cromoglycate.

tions used in the study ( $p<0.001$, fig 1). The inhibitory effect as measured by the maximal fall in FEV , after exercise was significantly greater at 10 , 20 , and $40 \mathrm{mg} / \mathrm{ml}$ than at $2 \mathrm{mg} / \mathrm{ml}(\mathrm{p}<0.05)$. A concentration of $20 \mathrm{mg} / \mathrm{ml}$ had the greatest protective effect of all, but when it was compared with 10 or $40 \mathrm{mg} / \mathrm{ml}$ the difference did not reach statistical significance. The mean FEV, returned to baseline values within 15 minutes when sodium cromoglycate was used at $20 \mathrm{mg}$ and $40 \mathrm{mg} / \mathrm{ml}$ and a small bronchodilator effect was noted at 30 minutes. In contrast, the mean $F E V_{1}$ remained below the baseline values over 30 minutes of recording with lower concentrations $(2 \mathrm{mg} / \mathrm{ml}$ and $10 \mathrm{mg} / \mathrm{ml}$, fig 1$)$.

\section{Discussion}

Sodium cromoglycate inhibited the fall in $\mathrm{FEV}_{1}$ at all concentrations used in the study and the protective effect increased from $2 \mathrm{mg} / \mathrm{ml}$ to $20 \mathrm{mg} / \mathrm{ml}$ (fig 2). Further, the mean $F E V_{1}$ returned to baseline values within 15 minutes after exercise when higher concentrations of the drug were inhaled $(20 \mathrm{mg} / \mathrm{ml}$ and $40 \mathrm{mg} / \mathrm{ml}$ ), with a slight bronchodilatory effect observed at 30 minutes. Recently Chung and Jones ${ }^{10}$ reported that sodium cromoglycate has a bronchodilator effect comparable to that of salbutamol. Our observations support the bronchodilator effect when cromoglycate is used in higher concentrations but this effect is rather small and of little therapeutic value.

Breslin and colleagues ${ }^{8}$ recently reported that sodium cromoglycate attenuates the obstructive response observed in asthmatic patients after hyperpnoea and airway cooling. These workers were, however, unable to confirm the hypothesis that with its great affinity for water the drug acted as a series heat exchanger with the respiratory mucosa. The studies comparing inhaled dry sodium cromoglycate with nebuliser solution are difficult to interpret because of the drug's hygroscopic property and also the variation in site and dose of drug deposited in the airways with different methods of administration. In this study we used sodium cromoglycate dissolved in water and delivered by the same technique to avoid these differences.

The mechanism of exercise-induced asthma remains unclear; both the vagal reflex through stimulation of airway irritant receptors and the release of mediator from the lung mast cell have been suggested. ${ }^{4} 512$ The vagal mechanism is apparently significant only in patients in whom the main 
site of airflow obstruction is the large airways. ${ }^{411}$ In contrast, sodium cromoglycate prevents exerciseinduced asthma in most patients. The close correlation between the bronchial hyperreactivity to exogenous histamine ${ }^{12}$ and the protective effect of sodium cromoglycate suggests that mediator release has an important role in exercise asthma. Recent studies have shown that cromoglycate also modifies and hastens recovery from bronchoconstriction induced by histamine and methacholine in asthmatic patients, and that this effect may be mediated through cholinergic or irritant receptors. ${ }^{1314}$ The recovery of patients within 15 minutes of exercise when sodium cromoglycate is used at higher concentrations is consistent with these observations. Further, the drug's protective effect in exercise asthma is dose related and may require adjustment for individual patients, and this may also be the case in allergen-induced asthma. We have observed recently that $40 \mathrm{mg}$ of cromoglycate (that is, two spincapsules) attenuates the exercise response in patients with exercise asthma in whom $20 \mathrm{mg}$ had previously failed to modify the fall in $\mathrm{FEV}_{\text {, }}$ after exercise. We have advised these patients to inhale the drug from two spincapsules before undertaking exercise. Jones and Chung have shown that the solution of sodium cromoglycate is far superior to the powder in inhibiting exercise-induced bronchoconstriction and that a much larger dose is required by dispersion of the dry powder through the spinhaler for conveying the drug to its site of action. ${ }^{6}$ Clearly dose-response studies of sodium cromoglycate with specific and non-specific bronchial challenges are required to clarify its additional properties and also its mechanism of action, and to enable us to achieve the right therapeutic dose for individual patients.

We thank Mrs Rita Jack for technical help and the pharmaceutical division of Fisons PLC for financial support.

\section{References}

' Orr TSC, Pollard MC, Gwilliam J, Cox JSG. Mode of action of disodium cromoglycate studies on immediate type hypersensitivity reaction using "double sensitisation" with antigenically distinct rat reagins. Clin Exp Immunol 1970;7:745-57.

${ }^{2}$ Davies SE. Effect of disodium cromoglycate on exercise-induced asthma. $\mathrm{Br}$ Med J 1968;iii:593-4.

${ }^{3}$ Godfrey S, König P. Inhibition of exercise-induced asthma by different pharmacological pathway. Thorax 1976;31:137-43.

4 Thomson NC, Patel KR, Kerr JW. Sodium cromoglycate and ipratropium bromide in exercise induced asthma. Thorax 1978;33:694-7.

${ }^{5}$ Anonymous. Arms and bronchi. Lancet 1976;i:287-9.

- Jones RS, Chung JTN. In: Pepys J, Edwards AM, eds. The mast cell: its role in health and disease. Tunbridge Wells: Pitman Medical, 1979:287-92.

${ }^{7}$ Cox JSG. Woodward GD, McCrone WC. Solid state chemistry of cromolyn sodium. J Pharm Sci 1971;60:1458-65.

${ }^{8}$ Breslin FJ, McFadden ER, Ingram RH. The effect of cromolyn sodium on the airway response to hyperpnoea and cold air in asthma. Am Rev Respir Dis 1980;122:11-6.

${ }^{9}$ Cotes JE. Lung function. 3rd ed. Oxford: Blackwell, 1975:380.

${ }^{10}$ Chung JTN, Jones RS. Bronchodilator effect of sodium cromoglycate and its clinical implications. $\mathrm{Br}$ Med J 1979;ii:1033-4.

" McFadden ER, Ingram RH, Haynes RL, Wellman JJ. Predominant site of flow limitation and mechanism of post exertional asthma. J Appl Physiol 1977;42:746 52.

12 Anderton RC, Cuff MT, Frith PA, et al. Bronchial responsiveness to inhaled histamine and exercise. $J$ Allergy Clin Immunol 1979;63:315-20.

${ }^{13}$ Woenne R, Kattan M, Levison H. Sodium cromoglycate-induced change in the dose-response curve of inhaled methacholine and histamine in asthmatic children. Am Rev Respir Dis 1979;119:927-32.

14 Woolcock AJ, Solome CM, Schoeffel RE. The effect of sodium cromoglycate on bronchial challenge with methacholine. In: Pepys J, Edwards AM, eds. The mast cell: its role in health and disease. Tunbridge Wells: Pitman Medical, 1979:271-9. 